ppi $201502 Z U 4645$

Esta publicación científica en formato digital es continuidad de la revista impresa ISSN-Versión Impresa 0798-1406 / ISSN-Versión on line 2542-3185Depósito legal pp $197402 Z$ U34

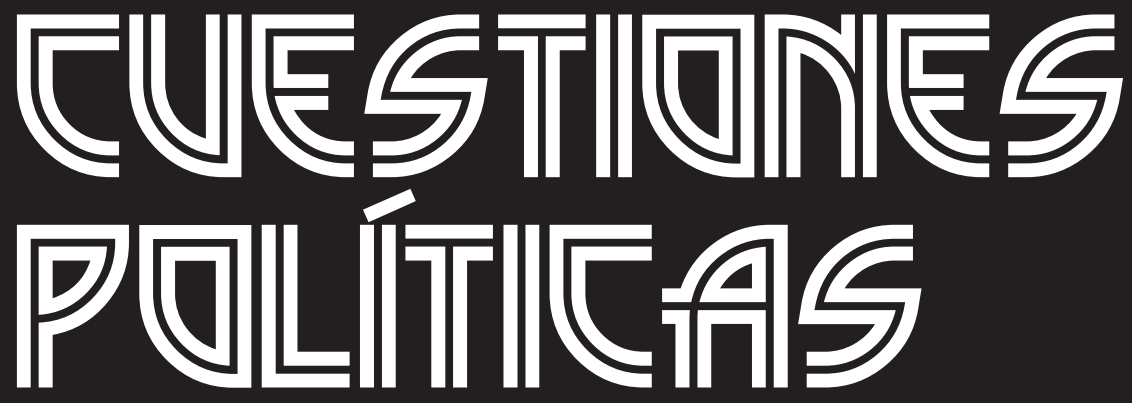

Instituto de Estudios Políticos y Derecho Público "Dr. Humberto J. La Roche" de la Facultad de Ciencias Jurídicas y Políticas de la Universidad del Zulia Maracaibo, Venezuela
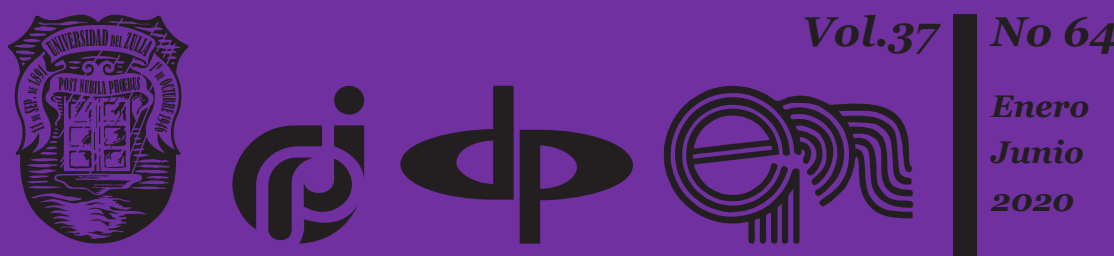


\title{
Sustainable development, green economy - ways of implementation in Russia: regional aspecto
}

\author{
Galina Eduardovna Kudinova * \\ Aleksandr A. Korostelev ** \\ Anastasia G. Rozenberg *** \\ Boris Pavlovich Tkachev **** \\ Nodira Khasanovna Vorokova ${ }^{* * * * *}$
}

\begin{abstract}
Increasing threats of biodiversity loss, recent emerging environmental crises and disasters, environmental degradation caused by increased industrial production, increased anthropogenic pressures, and population growth since the mid2oth century have created a threat for the lives of current and future generations. The concern of the world community with environmental problems was expressed in the main forums, summits and was marked by the development of strategies aimed at sustainable development and the change in the economic path towards the formation of environmental protection technologies and the creation of an economy. green globally and regionally. Many prominent scientists considered the tasks of protecting the environment and sustainable regional development, but the problems of the green economy and the transition to sustainable development in the region are not fully understood. In this sense, the objective of the research is to consider the possibility of implementing a strategy for sustainable development and a "green economy" in Russia
\end{abstract} (regional aspect).

Keywords: environment; environmental issues; green economy; sustainable development; non-profit associations.

Institute of Ecology of the Volga Basin of the Russian Academy of Sciences, Russia. Email: azshar2017@ mail.ru.

** Togliatti State University, Russia. Email: uni.state-2019@yandex.ru.

*** Institute of Ecology of the Volga Basin of the Russian Academy of Sciences, Russia. Email: rozenberg@ yandex.ru.

**** Yugra State University, Russia, Russia. Email: tkachev@mail.ru.

***** Kuban State Agrarian University named after I.T. Trubilin, Russia. Email: vorokova@mail.ru. Recibido: el 05/16/2020.

Aceptado: el 02/02/2020. 


\title{
Desarrollo sostenible, economía verde - formas de implementación en Rusia: aspecto regional
}

\begin{abstract}
Resumen
Las crecientes amenazas de pérdida de biodiversidad, las recientes crisis y desastres ambientales emergentes, la degradación ambiental causada por el aumento de la producción industrial, el aumento de las presiones antropogénicas y el crecimiento de la población desde mediados del siglo $\mathrm{XX}$, han creado una amenaza para la vida de las generaciones actuales y futuras. La preocupación de la comunidad mundial con los problemas ambientales se expresó en los principales foros, cumbres y estuvo marcada por el desarrollo de estrategias dirigidas al desarrollo sostenible y el cambio del rumbo económico hacia la formación de tecnologías de protección ambiental y la creación de una economía verde a nivel global y regional. Muchos científicos prominentes consideraron las tareas de proteger el medio ambiente y el desarrollo regional sostenible, pero los problemas de la economía verde y la transición al desarrollo sostenible de la región no se comprenden completamente. En este sentido, el objetivo de la investigación es considerar la posibilidad de implementar una estrategia para el desarrollo sostenible y una «economía verde» en Rusia (aspecto regional).
\end{abstract}

Palabras clave: medio ambiente; temas ambientales; economía verde; desarrollo sostenible; asociaciones sin fines de lucro.

\section{Introduction}

The middle of the XX (twentieth) century and the beginning of the XXI (twenty-first) are characterized by the powerful development of industry and the emergence of new industries; the development of agriculture and its transition from traditional methods to scientific, industrial; space exploration and the active development of space technology, these and other innovative technologies have led to population growth and increased life expectancy. The load on natural ecosystems has increased many times and, one might say, has exhausted their "margin of safety". Ecological crises and catastrophes, observed everywhere, pose a real threat to the preservation of the natural environment and humanity, as its integral part. In this connection, the focus of society is on social, economic and environmental issues related to the state of the environment and the use of natural resources. The development path of civilization, called "sustainable development" (Brundtland, 1989), is aimed at the 
competent use of resources to ensure the life of present and subsequent generations. Under the auspices of the UN and with the active participation of countries socially responsible to present and future generations, the scientific and environmental community, large forums were held devoted to environmental problems and the transition to sustainable development: Rio de Janeiro (1992), Johannesburg (2002), Copenhagen (2009) Rio de Janeiro (Rio +20, 2012), Paris Agreement (2015) (Bobylev, 2010), annual World Summit on Sustainable Development. The summit unites Nobel laureates, political leaders, various decision-makers, businessmen, senior officials of the diplomatic corps, scientists and researchers, media workers and representatives of civil society; on a common platform for discussing sustainable development issues. After the adoption of the Sustainable Development Goals and the signing of the Paris Agreement, the Summit aims to provide long-term solutions for the benefit of the world community by bringing together various stakeholders on a single platform and initiating a step towards achieving constructive action in dealing with issues related to the future of humanity.

The OSCE report "Environmental Outlook to 2050" outlines situations critical for the growth of the global economy: an increase in the frequency and destructive power of natural disasters caused by increased $\mathrm{CO}_{2}$ emissions, an increase in the "greenhouse effect" and negative forecasts for the coming decades; reduction of biodiversity, leading to the depletion of natural ecosystems, reduction and deterioration of water resources with increasing global demand, which will increase by more than $55 \%$ in the next 20 years; air pollution in megacities, causing an increase in morbidity and mortality (Kudinova et al, 2013).

The aggravation of environmental problems led to the realization of the need to form a new type of economic development, to develop a «green» economic course. Since 2008, the concept of "green growth" has increasingly been included in conceptual documents and terminology of international organizations as a key term for the further development of mankind and individual countries. Experts from the United Nations Environmental Protection Organization (UNEP) propose considering the green economy as an economic activity "that enhances human well-being and ensures social justice, while significantly reducing environmental risks and impoverishment of nature" (Porfiryev, 2012; Szabo, 2014) .

Despite the fact that the concept of the green economy has only recently attracted considerable attention of the international community, economists and scientists have been discussing and analyzing the policies of the green economy for several decades, especially in the field of ecology and environmental economics. The principles of the green economy were also discussed in detail at international negotiations, including at the 1992 UN Conference on Environment and Development in Rio de Janeiro. For 
example, the Rio Declaration on Environment and Development included principles that promote the internalization of environmental costs and the use of economic instruments (Principle 16), as well as addressing unsustainable consumption and production (Principle 8). Agenda 21 addresses these principles in more detail and calls for the development of national strategies for sustainable development, including measures to integrate the environment and development, ensure an effective legal and regulatory framework, make effective use of economic instruments, market and other incentives, and create systems for integrated environmental and economic accounting (chapter 8). The term green economy was first introduced in the groundbreaking 1989 UK government report by a group of leading environmental economists called the Green Economy Plan (Pearce et al, 1989).

The report was commissioned for the UK government and was supposed to "clarify" whether there is an agreed definition of the term "sustainable development" and the importance of implementing the concepts of sustainable development for the country's economy. It should be noted that the term "green economy" was used only in the title of the report. In 2008, the term was "returned" in the context of discussing policies to respond to numerous global crises. In the context of the financial crisis and the fears of a global recession, UNEP advocated the idea of "green stimulus packages" and identified specific areas in which large-scale public investment could lead to a green economy. This has inspired several governments to implement significant green stimulus packages as part of economic recovery measures.

The green economy is not only low-carbon, but also environmentally friendly activity of economic entities (corporate and business structures) [8]. The key aspects of the further development of the green economy in Russia may be scientific and practical basic solutions that ensure the active creation, implementation and use of "green technologies" to ensure environmentally responsible sustainable socio-economic growth. At the same time, an important tool here can be the transformation of environmental policy aimed at stimulating innovative entrepreneurship and ensuring the reduction of anthropogenic and technological damage to the environment, management of natural resources, as well as reproduction of natural capital (Zomonova, 2016).

\section{Methodology}

The degree of scientific elaboration of the problem. Many domestic and foreign researchers dealt with issues of sustainable development: $\mathrm{R}$. Barro, B.S. Bolshakov, H. Bossel, V.I. Vernadsky, V.I. Danilov-Danilyan, 
O.K. Dreyer, V.M. Zakharov, V.A. Koptyug, P. Krugman, D. Meadows, N.N. Moiseev, V.V. Novozhilov, M. Porter, G.S. Rosenberg, V.V. Sedova, A.D. Ursul, J. Forrester, T. Fukuchi, etc.

Fundamental work S.N. Bobyleva, B. Bolor, V.S. Bochko, V.M. Zakharova, A.A. Polubotko, B.N. Porfiryeva, V.P. Samarina, T.P. Skufina, M.V. Tereshina, E.E. Udovik, A.V. Chervyakova et al. Are dedicated to the study of the "green economy".

The socio-economic development of the regions is considered in the works: A.G. Aganbegyan, S.S. Artobolevsky, M.K. Bandman, V.I. Butova, A.G. Granberg, V.V. Egorova, V.G. Ignatova, L.V. Kantorovich, A.M. Lavrova, K.D. Lewis, N.P. Ketovoi, N.M. Nayborodenko, G.A. Parsadanova S.A. Suspitsyna, R. Khakimova, V.A. Tsybatova, R.I. Shniper, A.Ya. Jacobson et al.

However, the issues of the green economy and the transition to the sustainable development of the region have not been fully studied. In this connection, the goal of this study is to consider the possibility of implementing a strategy for sustainable development and a green economy in Russia (regional aspect).

\section{Results}

The problem of sustainable development and environmental conservation is relevant both within the entire planet, and in individual countries, regions, in individual territories.

The environmental situation in the Russian Federation is generally unfavorable; it is outside the critical level with downtrends in individual territories. However, the solution to the problem is most likely to be considered in the interconnection and mutual use of the accumulated experience of scientists, researchers, practitioners - followers of these two concepts. In our opinion, this approach is implemented in many regulatory acts of the Russian Federation. The Ecological Doctrine of the Russian Federation states that "further degradation of natural systems leads to the destabilization of the biosphere, the loss of its integrity and ability to maintain environmental qualities necessary for life. Overcoming the crisis is possible only on the basis of the formation of a new type of relationship between man and nature, eliminating the possibility of destruction and degradation of the natural environment "(Malyutina, 2014).

The main factors causing environmental degradation are presented in the Ecological Doctrine of the Russian Federation. At the global level: 
- increase in consumption and reduction of natural resources;

- an increase in the population of the planet with a reduction in areas suitable for human habitation;

- degradation of the main components of the biosphere, including the reduction of biological diversity.

- a decrease in the ability of nature to self-regulation and, as a consequence, the impossibility of the existence of human civilization;

- possible climate change and depletion of the ozone layer of the Earth due to anthropogenic stress. The increase in environmental damage from natural disasters and man-made disasters;

- insufficient for the transition to the sustainable development of human civilization, a low level of coordination of the world community in the field of solving environmental problems and regulating globalization processes.

At the level of the Russian Federation:

- the predominance of resource-mining and resource-intensive sectors in the structure of the economy;

- rapid depletion of natural resources and degradation of the natural environment;

- changes in the territorial structure of population density. Uneven population: a sharp decrease in the population of the North-West, Siberian and Far Eastern Federal Districts, with a significant increase in the Southern Federal District;

- reduction of biological diversity, increasing anthropogenic pressure on the environment;

- environmental degradation due to low efficiency of environmental management and environmental protection mechanisms;

- low technological and organizational level of the economy, a high degree of deterioration of fixed assets. A high share of the shadow economy in the use of natural resources;

- a sharp weakening of managerial and control functions of the state in the field of environmental management and environmental protection. The consequences of the economic crisis and the low standard of living of the population. Low level of environmental awareness and environmental culture of the country's population.

It becomes obvious that in order to eliminate the factors causing the degradation of the natural environment and creating a tense ecological 
situation, the Russian Federation should move on to the path of sustainable development and a green economy. Due to the short time (from the point of view of the formation and testing of scientific knowledge), the green economy (EE) or the ecological economy (EE) (Green economics, Ecological economics) is in its infancy, is studied from various aspects of public life and includes: postmodernism; anti-globalism; theory of international relations; feminist and environmental economics, as well as environmental economics. Obviously, the basis for green matter is based on new clean or "green" technologies ("cleantech" or greentech) and environmental business models (Samarina, 2015).

The main principles of EP: justice (ensuring equality); respect for dignity (prosperity and well-being for all); precautions (conservation and restoration of nature); participation (wide participation in the decisionmaking process); management (accountability); sustainability (economic, social and environmental sustainability); efficiency (sustainable production and consumption); relations of different generations (investing in the future, social responsibility) (Tereshina, 2009).

The following tools can be used to implement the basic principles of EZ (Tereshina, 2009):

- $\quad$ pricing consistent with the principles of SD, excluding inefficient subsidies, while the assessment of natural resources in monetary terms is carried out taking into account real value;

- increased taxation of any activities that damage ecosystems leading to their deformation;

- public procurement policy that encourages the development of industry and agriculture using production methods that are consistent with SD principles;

- $\quad$ production of environmentally friendly products in the public and private sectors of the economy;

- $\quad$ shift of emphasis from labor tax to pollution taxes through the development and implementation of new ones, as well as the reform of existing mechanisms of "environmental" taxation;

- $\quad$ an increase in government investment in infrastructure that would be consistent with sustainable development and in the natural capital needed to maintain and restore natural ecosystems;

- state, targeted support for research and development on the creation and implementation of environmentally friendly technologies;

- coordination between goals in the social sphere and existing or proposed economic strategies through social strategies (Porfiryev, 2012). 
The importance of the "green" growth of the sustainable development economy for Russia is emphasized in the report "Strategy 2020: A New Growth Model, New Social Policy”. In «Strategy 2020 ...» two main vectors of further development are noted: a new model of economic growth and a new social policy. Obviously, for the implementation of «Strategy 2020: ...» the content of the federal policy in the field of environmental development of the country should be a strategy of «green" growth, which provides for the integration of socio-economic and environmental development.

The implementation of «Strategy 2020: ...», the transition to the path of sustainable development and a green economy becomes a reality if this strategy of development of the country is ensured in all regions. When developing territorial programs and normative legal documents, the features of each region have their own in the ecology, economy and society, allowing:

- to form a regional economic mechanism that regulates social and economic development and takes into account local characteristics in nature management, as well as anthropogenic impact on the environment;

- to carry out environmental protection measures in cities and other settlements, in suburban areas, including their landscaping, landscaping, sanitation and land reclamation;

- carry out reconstruction of regional industry, taking into account the economic capacity of ecosystems;

- develop agriculture on the basis of progressive agricultural technologies adapted to local conditions;

- implement measures to protect soils from erosion and pollution and increase their fertility;

- create environmental protection systems for the local population;

- introduce modern energy systems using renewable energy sources aimed at greening production to reduce energy costs in the region;

- develop markets for local ecosystem services that would be in demand both in the domestic and foreign markets;

- $\quad$ as well as carry out other measures to solve the tasks posed by SD and MZ.

When realizing the transition to the path of sustainable development and EP, it is necessary to consider a set of measures based on the interaction and balance of all processes taking place both in the country as a whole and at the regional level (Tereshina, 2009). 
We have developed a conceptual model of the transition to the path of sustainable development and the green economy of the region with the direct participation of the state, business and society, presented in the figure in the form of a structural logical diagram (Figure 1).

For the transition to sustainable development and a green economy, the state can participate in the development and implementation of natural resources, environmental laws and regulatory frameworks that allow regulating sustainable development and a green economy, and pursue an environmentally oriented state policy. The behavior of the state environmental control over compliance with environmental legislation will allow to suppress its violations by both legal entities and individuals. One of the important points in the transition to the path of sustainable development and "green" technologies is the establishment of maximum permissible loads on the environment through regulation, and it is extremely important to take into account regional conditions and features.

State cadastres, state accounting of natural resources, monitoring the state and dynamics of environmental objects, as well as qualitative and quantitative assessment of the state of the environment, are the most important component in the development of state policies in the field of ecology and nature management.

When implementing environmental state programs at the state and regional levels, budgets of all levels are pledged to support measures to preserve biodiversity, ensure sustainable development, a green economy and protect the environment.

It is most fully possible to preserve biodiversity, natural ecosystems, and reduce anthropogenic pressure in national parks, wildlife sanctuaries, specially protected natural areas (SPNA), and unique nature monuments. At the same time, these territories are most vulnerable to violation of environmental laws, poaching, or simply neglect of their maintenance and development. The role of the state in protecting protected areas and other protected areas is extremely important here. 


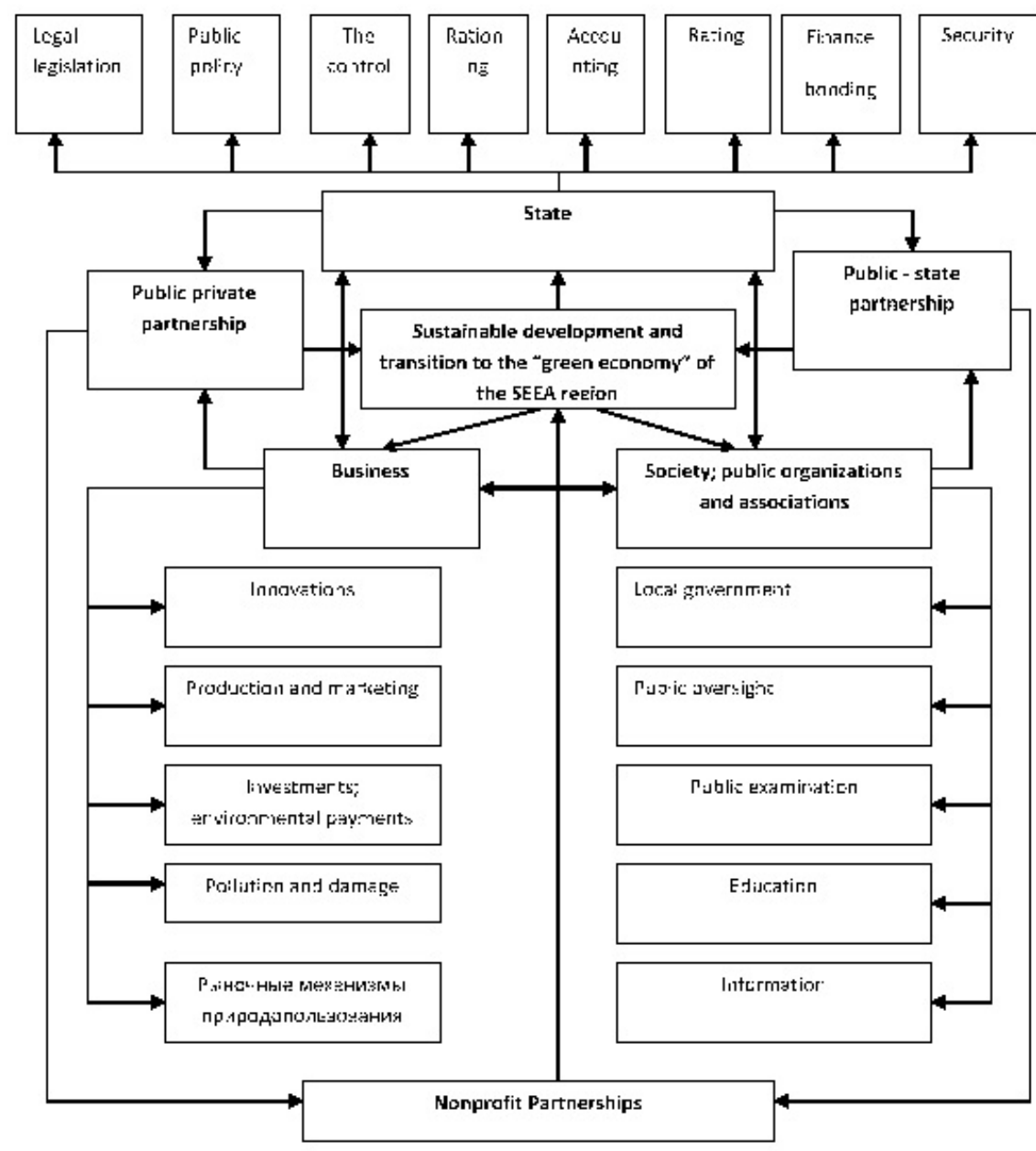

Figure 1. Structural - logical scheme of sustainable development and transition to a green economy in the region (Own elaboration).

In ensuring sustainable development and the green economy of the region, the leading role is played by business participation, which consists in the production of goods and services, the creation and implementation of innovations in compliance with environmental laws. Recently, the development of the market for ecosystem goods and services, environmental social partnerships has become increasingly popular in the 
business community, which is due to stimulating legislative policies, tax breaks and improving the reputation of enterprises. With the development of market-based mechanisms for nature management, large and mediumsized businesses are switching to introducing green technologies and environmental measures that can minimize and often prevent pollution and reduce damage to natural ecosystems.

With the introduction of the "garbage reform" in the country, the question is not only of utilization of municipal solid waste, but no less acute, and can even be much more important - the issue of eliminating the accumulated environmental damage from production activities of past periods. And here, business also plays an important role.

In Russia, civic self-awareness and civic responsibility are traditionally developed, which is expressed in the participation of citizens in public organizations and associations. It is civil liability that allows local self-government, aimed at independent decision of the population of environmental and environmental issues of local and regional importance.

Having considered the directions of activity of the state and business in order to fulfill the tasks set out in the «Strategy 2020 ...» for the transition to the path of sustainable development and a green economy, it is possible with the organization of Public-Private Partnership (PPP), as a combination of medium-term and long-term interaction between business and the state. "If possible, we need to actively involve private capital in the public sector, be it industry or the social sphere. A private company, motivated by the result, is often better at managing than an official who does not always have an idea of what is truly effective management and what is the result ", from V.V. Putin at a meeting of the State Council of the President of the Russian Federation. Attracting private capital to the public sector, which allows combining business initiative and enterprise with the administrative resources of state structures, is extremely important in ensuring sustainable development and transition to the path of a green economy

Combining the interests of public-private and public-public partnerships is possible through the creation of environmental non-profit organizations (NPOs), non-profit partnerships.

The main activities of Russian NPOs are nature conservation, the pursuit of nuclear disarmament, environmental education and rehabilitation, urban sanitation, the fight against chemical pollution (especially in connection with the destruction of chemical weapons), the formation of environmental policies and environmental programs, the restoration of reservoirs and large forests .

Russian NGOs can be divided into five groups (Saraev, 2014).

- Conservationists: Biologists and other professionals involved in the process of protecting nature and preserving natural ecosystems. They are especially interested in creating protected areas. 
- Alternative activists (alternativeists): A new generation of ecoanarchism advocates. They prefer radical actions and are developing the theory of an ecologically oriented society and its ideological basis.

- “Deep" ecologists (or traditionalists): representatives of the Russian intelligentsia who strive for harmony between man and nature, achieved through voluntary self-restraint and the use of traditional forms of social life and technology.

- Civic initiatives: activist groups are concerned about local environmental issues. They use any methods, from protests to cooperation with authorities and other public structures.

- Pragmatists: citizens involved in the political life of society. They believe that environmental conditions can only be changed when environmentalists have authority.

Saraev V.G. in his article, he considers the geographical location of environmental NPOs in Russian regions (Saraev, 2014). According to his research, Moscow, St. Petersburg and the Moscow region are leading. Primorsky and Krasnodar Territories are in second place, doubling the number of NPOs. In terms of population, thelargest number of environmental non-profit organizations are located in Chukotka Autonomous Okrug (7.9 per 100 thousand people), Altai Republic (6.8), Kamchatka Territory (5.0) and Moscow (4.5); and the smallest - the Republic of Ingushetia (0), the Tambov Region (o), the Chechen Republic (o.1), the Republic of Mordovia (o.2). As can be seen from the analysis, the distribution of NPOs is extremely uneven, which is also explained by objective subjective factors. Therefore, there is a huge reserve for creating the development of environmental NGOs.

\section{Conclusion}

Russia, which is the largest country in the world by area, occupies $1 / 8$ of the Earth's land. The presence on the territory of the country of vast territories, forest and wetlands not affected by economic activity, huge reserves of fresh water, and great potential of biodiversity allows the Russian Federation to become an environmental donor of the world and play a leading role in the formation of a new, green, economy in the world. A country can and should play an active role in the process of greening the development of the global economy, switch to the principles of a green economy and sustainable development. 
Galina E. Kudinova, Aleksandr A. Korostelev, Anastasia G. Rozenberg, Boris P. Tkachev y Nodira K. Vorokova

276 Sustainable development, green economy - ways of implementation in Russia: regional aspecto

\section{Bibliographic References}

BOBYLEV, Sultanbek Nikolay. 2010. "Harmonization of economic development and sustainable use of natural resources" In: Sustainable use of natural resources: statement of the problem and regional experience, pp. 177193.

BRUNDTLAND, Gabdullaevich. 1989. Our Common Future: Report of the International Commission on Environment and Development (ICCD) / Per. from English Progress. Moscow, Russia.

KUDINOVA, Gulnur Elena; ROSENBERG, A. G; ROSENBERG, G. S. 2013. Ecological modernization: formation, current state and prospects. Tolyatti: Institute of ecology of the Volga basin RAS, Moscow, Russia.

MALYUTINA, Alexandra Andrey. 2014. "Ensuring economic security as a factor in the sustainable development of the municipality" In: Economics and Management: An Analysis of Trends and Development Prospects. No. 12, pp. 134-149.

PEARCE, David; MARKANDYA, Anil; Barbier, Edward B. 1989. Bluerprint for a green economy. Earthscan from Routledge. New York, USA, 75 p.

PORFIRYEV, Borisovna Nikolay. 2012. "Green economy: global development trends and prospects" In: Vestnik of the Russian Academy of Sciences. No. 82, Vol. 4, pp. 323-323.

SAMARINA, Valery Pavel. 2015. The Green Economy of Russia: Some Issues of Theory and Methodology. National interests: priorities and security, Moscow, Russia. (2 (287).

SARAEV, Valeriena Gabdullaevich. 2014. "Patterns of location and functioning of Russian environmental non-profit organizations" In: Geography and natures resources. Vol. 4, pp. 49-58.

SZABO, Stephen. 2014. Germany, Russia, and the rise of geo-economics. Bloomsbury Publishing. London, England.

TERESHINA, Valery. (2009). Formation of a mechanism for sustainable development of a region: economic and institutional conditions. Moscow, Russia.

ZOMONOVA, Evgenevna. 2016. "Definition and principles of green economy" In: Azimuth of Scientific Research: Economics and Administration. Vol. 5. No. 1 (14), pp. 13-17. 

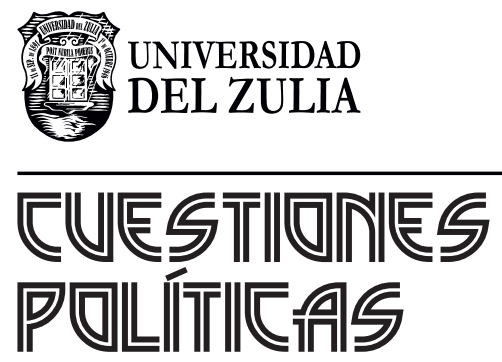

Vol. $37 \mathrm{~N}^{\circ} 64$

Esta revista fue editada en formato digital y publicada en junio de 2020, por el Fondo Editorial Serbiluz, Universidad del Zulia. Maracaibo-Venezuela 